180-191 J. Nat. Hist. Mus. Vol. 30, 2016-18

\title{
Ant diversity in Muhan Pokhari area of Shivapuri-Nagarjun National Park, Nepal
}

\author{
Prashant Neupane ${ }^{1}$ and Indra Prasad Subedi ${ }^{1}$
}

${ }^{1}$ Central Department of Zoology, Tribhuvan University, Kirtipur, Kathmandu, Nepal ipsubedi@cdztu.edu.np

\begin{abstract}
Ant diversity was studied in Muhan Pokhari area of Shivapuri-Nagarjun National Park (SNNP) at $1,700 \mathrm{~m}$ to $1,900 \mathrm{~m}$ asl during winter and summer seasons of 2017 . Ants were collected using pitfall traps, leaf litter sampling, bait and hand collection methods along a transect of $50 \mathrm{~m}$ in each of all 5 sites $(1,700 \mathrm{~m}, 1,750 \mathrm{~m}, 1,800 \mathrm{~m}, 1,850 \mathrm{~m}$ and 1,900 m). Altogether 817 individual ants were collected representing 5 sub-families, 16 genera and 23 morpho species. Formicinae $(57.67 \%)$ was the most abundant sub-family, followed by Myrmicinae $(40.39 \%)$, Pseudomyrmicinae $(0.8 \%)$, Ponerinae $(0.73 \%)$ and Dolichoderinae $(0.37 \%)$.Camponotus (437individuals) was the most abundant genus followed by Aphaenogaster (287). Species richness was higher in winter (17 morph species) than in spring (14 morph species). ShannonWiener diversity index (1.4618) and Evenness index (0.5539) were higher in spring season. Pitfall trap method was found most effective with highest number of individual ants (567) and of 21 species. The Shannon-Weiner diversity index was highest for pitfall method (1.3039) whereas evenness index was highest for the bait method (0.62615). Two genera Pachycondyla and Echinopla were were recorded for the first time in Nepal.
\end{abstract}

Keywords: Camponotus, Echinopla, Formicid fauna, Pachycondyla, SNNP

\section{INTRODUCTION}

Ants are one of the most abundant and diverse animal groups in tropical ecosystems (Stork, 1991). They are the important components of the ecosystem not only because they constitute the great proportion of animal biomass but also they are the ecosystem engineers. They are further significant to alter the physical and chemical environment and can cause the impact upon the plants, microorganisms and the other soil fauna (Folgarait, 1998). Ants perform a variety of roles such as herbivores, predators, scavengers, seed dispersers, plant and arthropod mutualists, and soil engineers (Andersen et al., 2002; Sanders et al., 2003; Maeto \& Sato, 2004) and good indicators of ecological condition (Agosti et al., 2000; Andrew et al., 2000; Read \& Andersen, 2000; Bestelmeyer \& Wiens, 2001; Andersen et al., 2002; Andersen et al., 2003; Maeto \& Sato, 2004) for many reasons such as they are a diverse group, sensitive to environmental change, easily collected and assist in important ecological functions (Alonso \& Agosti, 2000).

Currently, there are 17 extant subfamilies, 333 genera, 13,263 species, 1,941 subspecies of ants in the world (Bolton, 2017) whereas 144 species/subspecies of ants known to Nepal belonging to 8 subfamilies, 58 genera including 9 endemic and 5 introduced species (Bharti 
Neupane and Subedi: Ant diversity in Muhan pokhari area of Shivapuri

\& Subedi, 2017). Collingwood (1970) provided the first list of 34 species of Nepalese ants. Elmes \& Radchenko (2009) added two new Himalayan Ant species (Hymenoptera, Formicidae) from Makalu Barun National Park, Nepal. Wetterer (2017) mapped Nepal as one of the 21 countries of Asia for the geographical distribution of weaver ant, Oecophylla smaragdina. Bharti et al. (2009) in their study of seasonal patterns of ants in Punjab Shivalik found that the species richness was maximum during summer season $\left(36.54^{\circ} \mathrm{C}\right.$ - $20.81^{\circ} \mathrm{C}$ ), a total of 40 species representing 24 genera and 8 sub- families (Myrmicinae, Ponerinae, Cerapachyinae, Formicinae, Dolichoderinae, Dorylinae, Aenictinae and Pseudomyrmicinae) were collected during this season, whereas in winter season $\left(19.6^{\circ} \mathrm{C}\right.$ $2.26^{\circ} \mathrm{C}$ ) only 5 species belonging to 5 genera and 3 sub- families (Myrmicinae, Formicinae and Dolichoderinae) were reported.

No single ant sampling method is perfect for collection of a wide range of species and different sampling methods designed for ant sampling are not equally effective. Therefore, a good combination of different methods is essential for the ecological surveys. Different sampling methods when used in the same habitat, each of them will contain a few unique species that are not represented in any other sampling method (Longino \& Colwell, 1997). In structured inventory, it is commonly recommended that a diversity of methods should be simultaneously used to yield the most species-rich inventory (Bestelmeyer et al., 2000; King \& Porter, 2005; Lopes \& Vasconcelos, 2008). Leaf litter sampling can form a good composite technique with pitfall trapping (Olson, 1991). Pitfall traps are cost-effective techniques and are probably most widely and frequently used method for sampling ground-dwelling ants but may not be effective for species associated with soil, deep litter and vegetation (Majer, 1997). Bait traps are effective for collecting live ants. Hand collecting gives good results for comparative studies of ant assemblages across habitats than litter sampling or pitfall traps because it can be easily sampled ant fauna in different environmentally sensitive sites such as rocks, slopes, human and animal disturbance (Gotelli et al., 2010).

\section{MATERIALS AND METHODS}

\section{Study area}

The study was carried out in Muhan Pokhari area of Shivapuri - Nagarjun National Park (SNNP) which is located in the north side of Kathmandu valley. SNNP has two islands of forests namely Shivapuri and Nagarjun. The park area is surrounded by heavy sub-urban population. Geographically Shivapuri forest is located within $27^{\circ} 45^{\prime}$ to $27^{\circ} 52^{\prime} \mathrm{N}$ latitude and $85^{\circ} 16^{\prime}$ to $85^{\circ} 45^{\prime} \mathrm{E}$ longitude and Nagarjun forest is located within $27^{\circ} 43^{\prime}$ to $27^{\circ} 46^{\prime} \mathrm{N}$ latitude and $85^{\circ} 13^{\prime}$ to $85^{\circ} 18^{\prime}$ E longitude. It claims part of Kathmandu, Nuwakot, Dhading, and Sindhupalchowk districts of Nepal. The elevation range is $1,350 \mathrm{~m}$ asl to $2,732 \mathrm{~m}$ asl. SNNP represents subtropical and lower temperate zone of Nepal. The park has four distinct types of forests along the altitudinal gradients: lower mixed hardwood forest, chirpine forest, upper mixed hardwood forest and oak forest. The study sites ranged between 1,700-1,900 m asl consisting of two types of forests. Pinus roxburghii is dominant plant species in the altitudinal range of 1,600 $\mathrm{m}-1,800 \mathrm{~m}$ in the study area. Similarly, at an altitude of $1,800-2,300 \mathrm{~m}$ asl, Rhododendron abroreum and Quercus lanata were frequently dominant among the tree species. 


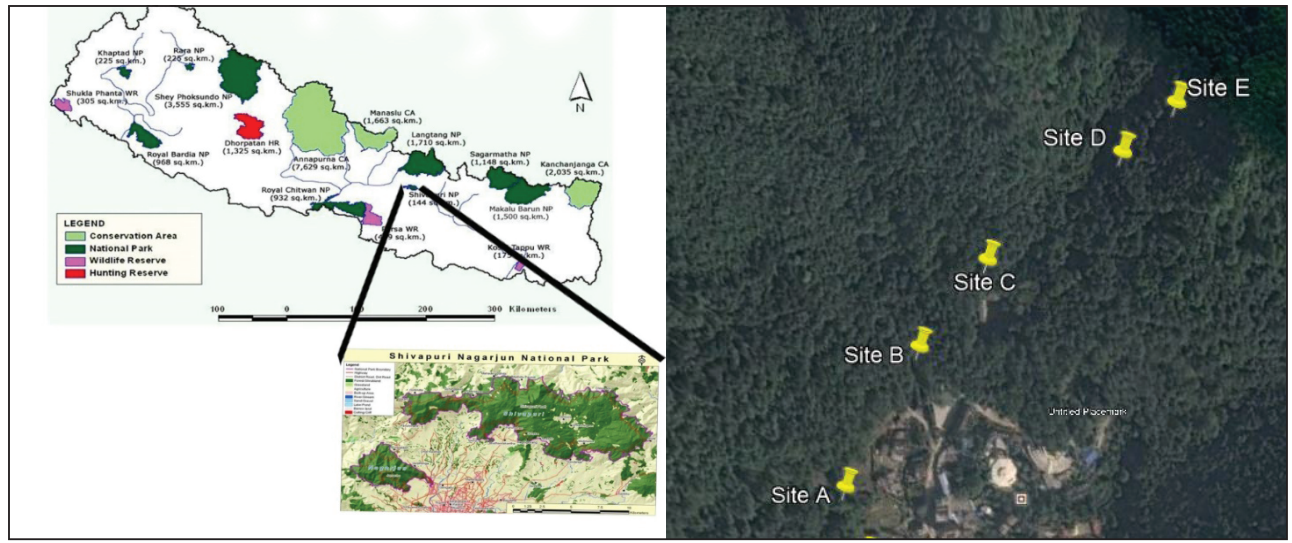

FIG. 1. Map of study area.

\section{Ant sampling}

Samples were collected from Muhan Pokhari area of SNNP dividing the study area into five sites situated in 1,700 m (site A), 1,750 m (Site B), 1,800 m (Site C), 1,850 m (Site D) and $1,900 \mathrm{~m}$ (Site E) altitudes. Surveys were performed in each month of winter and spring seasons of 2017 using pitfall traps, cookie baits, leaf-litter sifting and hand collection methods. Sampling sites were selected randomly. Site A, B and C were close to moist area of forest and site $D$ and $E$ were far from moist area of the forest.

Pitfall traps: In each sampling site, ten pitfall traps were kept maintaining a distance of $5 \mathrm{~m}$ between adjacent traps. Pitfall traps were made up of plastic bottles with an internal diameter of $9 \mathrm{~mm}$ and a depth of $150 \mathrm{~mm}$, which were partly filled to a depth of about $50 \mathrm{~mm}$ with soapy water and $5 \%$ ethylene glycol solution, and buried in the soil surface. Traps were set for 15 days each time.

Litter shifting: A quadrat of size $1 \mathrm{~m} \times 1 \mathrm{~m}$ was thrown in 10 spots randomly in each site. The leaf litter inside each quadrat ( $1 \mathrm{~m}^{2}$ plot) was collected and sifted through a sieve of mesh size $5 \mathrm{~mm}$. The ants were collected from sifted litter and preserved in $70 \%$ alcohol.

Biscuits were used in the form of bait and kept for 45 minutes. Baits were also placed near the pitfall traps. The ants hovering around the bait were collected in the vials. In hand picking method, the samples were collected from the tree twigs and ground by hand or the forceps and kept in vials.

Cookie baits: Ten cookie baits were placed on $8 \times 8 \mathrm{~cm}$ squares of paper towel and set out $5 \mathrm{~m}$ apart in each site. Sampling was done from 11:00 hrs to 15:00 hrs, enabling to capture only diurnal ants. The bait was exposed for 45 minutes and ants in each bait were collected.

Hand collection: Ants were also surveyed through general collecting by searching in rotten logs and stumps, in dead and live branches, on low vegetation, on the ground, under moss and under stones. At each site, general collection was conducted for an approximately 2 hours. 


\section{Identification}

The collected specimens were identified using standard taxonomic keys (Bolton, 1994; Bingham, 1903), by comparing labeled specimens, comparing with type images available in the Antweb and comparing with descriptions.

\section{Data analysis}

Ant species richness, mean abundance were analyzed by using Shannon-Wiener diversity index and Evenness index (Zar, 1999).

\section{Ethical statement}

The necessary permit for the described field study was obtained from DNPWC. The proposed study does not involve endangered or protected species.

\section{RESULTS AND DISCUSSION}

A total of 817 ants were collected representing 5 sub- families (Dolichoderinae, Formicinae, Myrmicinae, Ponerinae and Pseudomyrmicinae), 16 genera and 23 morphospecies. Subfamily Formicinae possessed 6 genera with 11 morphospecies, Myrmicinae with 6 genera and 8 morphospecies, Dolichoderinae and Pseudomyrmicinae with one genus and one morphospecies each and Ponerinae with 2 genera and 2 mophospecies. Out of 16 genera, 2 genera (Pachycondyla and Echinopla) are new to Nepal. 471 individual ants belonged to sub- family Formicinae, 330 belonged to Myrmicinae, 7 to Pseudomyrmicinae, 6 to Ponerinae and 3 to Dolichoderinae (fig. 2).

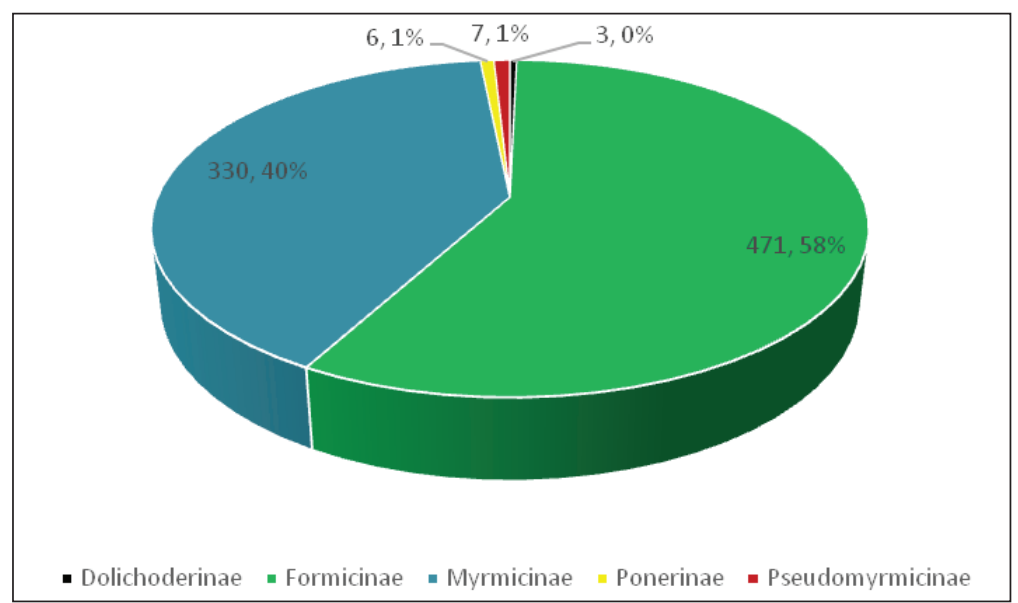

FIG. 2. Sub- family wise abundance of ant specimens in SNNP.

This conclusion was very similar to the study of the ants in the Saline Dry Lake Chott El Hodna in Algeria, a Ramsar Conservation Wetland where a total of 928 ant individuals were collected ( 682 by pitfalls, 246 by hand) representing 24 species belonging to 14 genera and 4 sub- families (Barech et al., 2016). Out of 16 genera recorded from the study site, most morphospecies rich 
genera was Camponotus (5 morphospecies), followed by Aphaenogaster and Polyrachis with 2 morphospecies each. Thirteen genera (Technomyrmex, Formica, Lasius, Oecophylla, Echinopla, Crematogaster, Pheidole, Pheidologeton, Monomorium, Myrmica, Odontoponera, Pachycondyla and Tetraponera) had one morphospecies each with Echinopla having a single specimen. These results agree with the study that recorded Camponotus as one of the most occurring genera globally (Wilson, 1975).

In this study, Camponotus and Aphaenogaster were found to be most abundant genera, occurring almost $85 \%$ of samples. Out of 23 morphospecies, Aphaenogastersp. 1 was the most of abundant, occurring in almost $17.38 \%$ of samples. Species richness (23) from 16 genera of SNNP is similar to ant collection in oak- dominated mixed forests (32) from 17 genera in Australia. Similarly, subspecies Formicinae and Myrmicinae consisted $95.34 \%$ of the total ants which is quite similar to $92.81 \%$ of the total ants of sub- family Formicinae and Myrmicinae recorded from Jammu- Kashmir Himalaya I from altitudinal gradient of $1000 \mathrm{~m}$ to $2000 \mathrm{~m}$ asl (Bharti \& Sharma, 2009). Camponotus (Formicinae), Echinopla (Formicinae), Crematogaster (Myrmicinae), Oecophylla (Formicinae) and Pheidole (Myrmecinae) are shown in plate 1,2,3,4, and 5 respectively in appendix 1.

\section{Ant diversity in different habitats}

The Pinus roxburghii forest is present within an altitude of 1,600 - 1,800 m. Thus, this forest includes three lower sites (1,700 m, 1,750 m and 1,800 m). Similarly, Quercus-Castanopsis Rhododendron forest is present within an altitude of $1,800-2,300 \mathrm{~m}$. Thus, this forest includes the upper two sites of the study area i.e. $1,850 \mathrm{~m}$ and 1,900 $\mathrm{m}$.

In site $A(1,700 \mathrm{~m}$ asl), species richness $(\mathrm{S})$, Shannon's index of species diversity $(\mathrm{H})$ and evenness index $(\mathrm{J})$ were calculated as $\mathrm{S}=9, \mathrm{H}=1.1468$ and $\mathrm{J}=0.52193$. Technomyrmex sp was the species present only at this site. In site B (1,750 $\mathrm{m}$ asl), species richness (S), Shannon's index of species diversity $(\mathrm{H})$ and evenness index $(\mathrm{J})$ were calculated as $\mathrm{S}=12, \mathrm{H}=0.99$ and $J=0.3984$. In site $C(1,800 \mathrm{~m}$ asl), species richness $(S)$, Shannon's index of species diversity $(\mathrm{H})$ and evenness index $(\mathrm{J})$ were calculated as $\mathrm{S}=11, \mathrm{H}=1.448$ and $\mathrm{J}=0.60384$. Oecophylla $\mathrm{sp}$, Odontoponera sp and Myrmica sp were recorded only at this site. In site $D(1,850 \mathrm{~m}$ asl), species richness $(\mathrm{S})$, Shannon's index of species diversity $(\mathrm{H})$ and evenness index $(\mathrm{J})$ were calculated as $\mathrm{S}=8, \mathrm{H}=1.0257$ and $\mathrm{J}=0.49327$. Echinopla sp and Pheidologeton sp were the species collected only from this site. In site $E(1,900 \mathrm{~m}$ asl), species richness (S), Shannon's index of species diversity $(\mathrm{H})$ and evenness index $(\mathrm{J})$ were calculated as $\mathrm{S}=10, \mathrm{H}=0.8191$ and $\mathrm{J}=0.35575$. This result corresponds with the study of Bruhl et al. (1993) in altitudinal range from $560 \mathrm{~m}-2600 \mathrm{~m}$ asl in primary forests on Mount Kinabalu in terms of elevationwise species richness where species richness was highest at mid elevation. This study did not coincide with the species richness along an elevation gradient (400 m-1860 m) where the species richness was greatest at $400 \mathrm{~m}$ and $780 \mathrm{~m}$ and least at $1860 \mathrm{~m}$ (Fisher, 2002). The research of ants by analyzing litter ant diversity in the Wayanad region of Western Ghats in Kerela, Southern India showed the highest ant abundance and species richness at midelevation (Sabu et al., 2008). The investigation of ant species diversity, species richness and abundance along an elevation gradient in Jammu- Kashmir Himalaya showed that ant species richness increased with an initial increase in elevation, peaked at mid- elevation and thereafter decreased, thus forming a mid- elevation peak (Bharti et al., 2013). On contrary, diversity 
patterns of ants were surveyed along an elevation gradient on Monts Doudou in southwestern Gabon which showed a different result. Ants were collected at three elevations (110 m, 375 $\mathrm{m}, 640 \mathrm{~m}$ ). Species richness was relatively constant along the elevational gradient surveyed. Comparison of ant species turnover along the gradient did not show evidence of variation with respect to elevation (Fisher, 2004). Only two genera, Camponotus and Aphaenogaster were found common in all the sites. No morphospecies was common to all the sites, thus the research done by taking altitudinal gradient was proven effective.

\section{Seasonal diversity}

Five sub- families, 12 genera and 17 morphospecies were collected from winter season and 5 sub- families, 12 genera and 14 morphospecies were collected from spring season. 3 genera (Oecophylla, Odontoponera and Pheidologeton) were peculiar to winter season and 4 genera (Monomorium, Crematogaster, Echinopla and Pheidole) were peculiar to spring season.

Maximum species richness (11) was recorded in winter season as compared to spring season, which recorded species richness (8). Similarly, Shannon index of species diversity $(H)$ and, Evenness index $(\mathrm{J})$ was recorded as highest during spring season as $\mathrm{H}=1.4328$ and $\mathrm{J}=$ 0.89022 at site $\mathrm{C}$ whereas in winter it was recorded as $\mathrm{H}=1.2573$ at site $\mathrm{C}$ and $\mathrm{J}=0.7335$ at site $A$ though, more number of individual ants were collected (576 individuals) in winter compared to spring (241 individuals) season. Similarly, Shannon index of species diversity was found higher during spring season all sites except site D. Abundance of ants of every site was maximum in winter season with an exception of site $A$ (table 1, fig. 3 ).

TABLE 1. The species richness, Shannon index of species diversity, evenness index and abundance of ants in different sites (A, B, C, D and E) of SNNP in winter and spring season.

\begin{tabular}{|l|l|l|l|l|l|}
\hline \multirow{5}{*}{ Season } & Site & $\begin{array}{c}\text { Species } \\
\text { Richness } \\
\text { (S) }\end{array}$ & $\begin{array}{c}\text { Shannon index of } \\
\text { species diversity } \\
\text { (H) }\end{array}$ & $\begin{array}{c}\text { Evenness } \\
\text { Index (J) }\end{array}$ & $\begin{array}{c}\text { Number of } \\
\text { ants col- } \\
\text { lected }\end{array}$ \\
\hline \multirow{5}{*}{ Winter } & A & 3 & 0.8058 & 0.7335 & 46 \\
\cline { 2 - 7 } & B & 7 & 0.6939 & 0.35657 & 221 \\
\cline { 2 - 6 } & C & 11 & 1.2573 & 0.52435 & 121 \\
\cline { 2 - 6 } & D & 8 & 0.8697 & 0.41826 & 102 \\
\cline { 2 - 6 } & E & 3 & 0.6798 & 0.61881 & 86 \\
\hline \multirow{5}{*}{ Spring } & A & 8 & 1.1628 & 0.5592 & 69 \\
\cline { 2 - 6 } & B & 5 & 1.389 & 0.86301 & 48 \\
\cline { 2 - 6 } & C & 5 & 1.4328 & 0.89022 & 28 \\
\cline { 2 - 6 } & D & 2 & 0.1849 & 0.26676 & 22 \\
\cline { 2 - 6 } & E & 7 & 0.7454 & 0.38305 & 74 \\
\hline
\end{tabular}




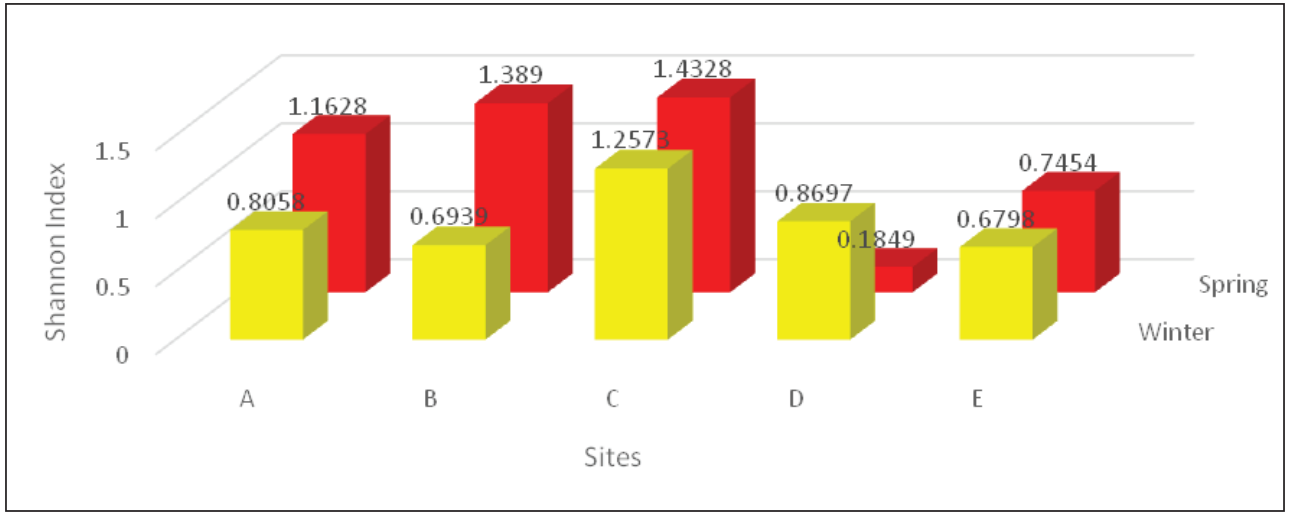

FIG. 3. Shannon-Weinner diversity index $(H)$ of different sites in Winter and Spring seasons at an altitude of $1,700 \mathrm{~m}$ to $1,900 \mathrm{~m}$ asl.

The amount of energy available in a system (primary productivity) is thought to be one of the major determinants of species diversity, especially species richness and thus the community composition also changed (Turner \& Foster, 2009). This study showed higher ant abundance during the winter season than in spring season which may be due to the climatic differences. This conclusion is mostly contrasting to the conclusion drawn by some of the researchers as for seasonal pattern of ants was studied in five seasons in Punjab Shivalik range of NorthWest Himalaya which concluded that only 5 species were recorded during winter season and 40 species during summer season (Bharti et al., 2009). Similarly, composition and activity patterns of ants were observed by various methods in three different habitats in summer and winter in the semi-arid Karoo, South Africa which showed the result that ant abundance was greater during summer than winter (Lindsey \& Skinner, 2001).

\section{Sampling efficacy of different methods}

Pitfall method collected maximum ant individuals (567) followed by bait method (88), leaf litter sampling method (82) and manual hand collection (80). Majority of ants collected by pitfall method included Camponotus sp.1, Camponotus sp.2, Camponotus sp.3, Camponotus sp.4, Camponotus sp.5, Aphaenogaster sp.1 and Aphaenogaster sp.2. Ten species (Monomorium sp., Polyrachis sp. 1, Polyrachis sp.2, Oecophylla sp., Odontoponera sp., Pheidole sp.1, Pheidole sp.2, Pheidologeton sp., Echinopla sp. and Myrmica sp) were collected only through pitfall method. Tetraponera sp. was collected only through bait method and Technomyrmex sp was collected only through leaf litter sampling (fig. 4, table 2).

Shannon diversity index was highest for pitfall method (1.3039) followed by bait method (1.0078). Leaf litter sampling (0.2707) had the least value of Shannon diversity index. On the contrary, the value of evenness index was maximum (0.62615) for bait method, followed by pitfall method (0.42829), leaf litter sampling (0.19565) and hand collection (0.1432). Shannon diversity index and Evenness index of handpicking method was not compared with other methods because effectiveness of handpicking method cannot be standardized for effectiveness comparison as it is an opportunistic sampling. 


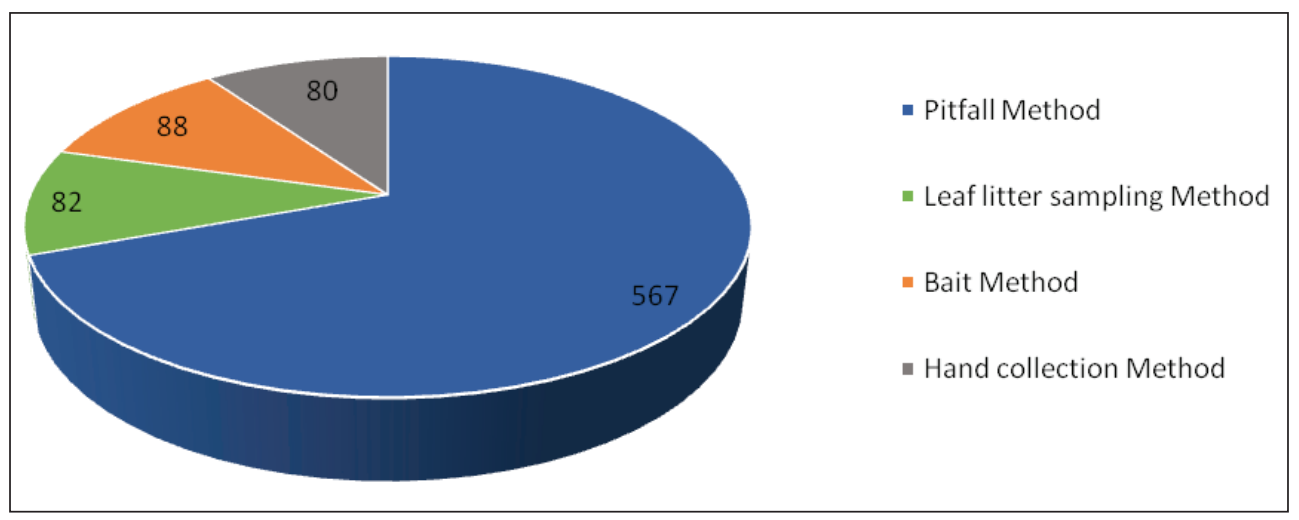

FIG. 4. Abundance of ants collected through different methods.

TABLE 2. The ant genera collected from specific collection methods.

\begin{tabular}{|l|l|l|l|l|l|l|l|l|l|l|}
\hline \multicolumn{1}{|c|}{ Season } & \multicolumn{3}{|c|}{ Winter } & \multicolumn{5}{c|}{ Spring } \\
\hline Site & A & B & C & D & E & A & B & C & D & E \\
\hline Genus & & & & & & & & & & \\
\hline Technomyrmex & L & - & - & - & - & - & - & - & - & - \\
\hline Formica & - & - & PLB & - & - & PL & P & - & - & PL \\
\hline Polyrachis & - & - & - & P & - & - & P & - & - & P \\
\hline Camponotus & PLH & PLB & P & PL & P & P & PL & P & P & P \\
\hline Lasius & - & - & PLB & PL & - & PL & - & - & - & - \\
\hline Oecophylla & - & - & P & - & - & - & - & - & - & - \\
\hline Echinopla & - & - & - & - & - & - & - & - & P & - \\
\hline Aphaenogaster & PLH & P & P & PL & PB & - & PB & P & - & - \\
\hline Crematogaster & - & - & - & - & - & - & PH & PLH & - & PL \\
\hline Pheidole & - & - & - & - & - & P & - & - & - & P \\
\hline Pheidologeton & - & - & - & P & - & - & - & - & - & - \\
\hline Monomorium & - & - & - & - & - & - & P & P & - & - \\
\hline Myrmica & - & - & - & - & - & - & - & PL & - & - \\
\hline Odontoponera & - & - & P & - & - & - & - & - & - & - \\
\hline Pachycondyla & - & - & - & P & - & PLB & - & - & - & - \\
\hline Tetraponera & - & B & - & - & - & - & - & - & - & - \\
\hline
\end{tabular}

The study has shown considerable variation of the ant community due to different methods. There was variation in the total individuals of the ants collected, the species richness, Shannon diversity index and evenness index between the different methods (bait, leaf litter, pitfall and manual hand collection) applied. The highest number of ants (567) was collected in pitfall 
traps since they were kept for longer duration and they sample both diurnal and nocturnal ants. This result was similar to the examination of ants in the Fall-Line Sandhills, at Fort Benning, Georgia where 137,355 ants were identified and counted in pitfall traps, 1,295 in sweep nets, and 2,818 on trunks of pine and oak. Pitfall method was the most successful method of ant collection (21 morphospecies) followed by bait method ( 5 morphospecies) and leaf litter sampling (4 morphospecies) and hand collection (4 methods). This finding coincides with the study done upon the ant by using different techniques in eight different localities in the Venezuelan Llanos, Savannas the best result of ant collection was obtained by a combination of hand collecting and pitfall traps (Romero and Jaffe, 1989). Similarly, comparison of litter and soil ant fauna has shown that a combination of pitfalls, litter sifting, baiting and hand sorting increase the efficiency of species captures in comparison to any single method by itself (Majer \& Delabie, 1994). This study also corresponds to the survey of ants performed in 12 localities in Uttara Khannada districts of Karnataka which yielded 31 genera with 120 species and concluded that pitfall method as the most successful method with 28 genus and 91 species collected (Gadagkar et al., 1993). In the same way, composition and activity patterns of ants was observed by various methods (pitfall method, quadrant method and dig sampling method) in three different habitats in summer and winter in the semi-arid Karoo, South Africa which concluded that pitfall method recorded the most species as compared to dig sampling or quadrat sampling (Lindsey \& Skinner, 2001). Similarly, pitfall method and bait method were compared for studying ant litter community in oak-dominated mixed vegetation during 1995-1997 which concluded that pitfall method was more successful than bait method as bait traps caught 29 species whereas pitfall trap caught 31 species. Similarly, ant diversity and abundance was studied along the elevation gradient in Philippines using pitfall and hand collection methods where pitfall method recorded 51 species of ants and hand collection yielded 48 species (Samson et al., 2006).

\section{ACKNOWLEDGEMENTS}

Authors are grateful to Department of National Park and Wildlife Conservation (DNPWC) and Shivapuri - Nagarjun National Park Management for providing permission to collect ant species from the National Park.

\section{REFERENCES}

AGOSTI, D; ALONSO, L E (2000) The ALL protocol: A standard protocol for the collection of grounddwelling ants. In AGOSTI, D; MAJER, J D; ALONSO, L E; SCHULTZ, T (eds) Ants: standard methods for measuring and monitoring biodiversity. Smithsonian Institution Press; Washington DC, USA; pp 2042206.

AGOSTI, D; MAJER, J D; ALONSO, L E; SCHULTZ, T R (2000) Ants: standard methods for measuring and monitoring biodiversity. Washingtonand London: Smithsonian Institution Press, Washington DC, USA.

ANDERSEN, A N; HOFFMAN, B D; MULLER, W J; GRIFFITHS, A D (2002) Using ants as bioindicators in land management: simplifying assessment ofant community responses. Journal of Applied Ecology 39 : 8-217.

ANDERSEN, A N; HOFFMANN, B D; SOMES, J (2003) Ants as indicators of minesite restoration: community recovery at one of eight rehabilitation sites in central Queensland. Ecological Management and Restoration 4(I): 12-219. 
ANDREW, N; RODGERSON, L; YORK, A (2000) Frequent fuel-reduction burning: the role of logs and associated leaf litter in the conservation of ant biodiversity. Australian Journal of Ecology 25(1): 99-2107.

BARECH, G; KHALDI, M; ZIANE, S; ZEDAM, A; DOUMANDJI, S; SHARAF, M; ESPADALE, X (2016) A first checklist and diversity of ants (Hymenoptera: Formicidae) of the Saline Dry Lake Chott El Hodna in Algeria, a Ramsar Conservation Wetland. African Entomology 24: 143-2152.

BESTELMEYER, B T; AGOSTI, D; ALONSO, L E; BRANDAO, C R F; BROWN, W L JR; DELABIE J H C; SILVESTRE R (2000) Field techniques for the study of ground-dwelling ants: an overview, description, and evaluation. In Agosti, D; Majer, J D; Alonso, LE; Schultz, TR (eds) Ants: standard methods for measuring and monitoring biodiversity. Smithsonian Institution Press; Washington, DC, USA; pp 122-2144.

BESTELMEYER, B T; WIENS, J A (2001) Ant biodiversity in semiarid landscape mosaics: the consequences of grazing vs. natural heterogeneity. Ecological Applications 11(4): 1123-21140.

BHARTI, H; SHARMA, Y P; BHARTI, M; PFEIFFER, M (2013) Ant species richness, endemicity and functional groups, along an elevational gradient in the Himalayas. Asian Myrmecology 5: $79-101$.

BHARTI, H; SHARMA, Y P; KAUR, A (2009) Seasonal patterns of ants (Hymenoptera: Formicidae) in Punjab Shivalik. Halteres, 1(1): 36-247.

BHARTI, H; SUBEDI, I P (2017) Antweb: Ants of Nepal. Available at https://www.antweb.org/country. do?name=Nepal.

BOLTON, B (1994) Identification guide to the ant genera of the world. Harvard University Press, Cambridge, USA.

BOLTON, B (2017) An online catalog of the Ants of the world. Available at http://www.antcat.org.

BOLTON, B (2018) Antweb: Ants of Bolton World Catalogue. Available at https://www.antweb.org/project. do?name=worldants.

BRUHL, C A; MOHAMED, M; LINSENMAIR, K E (1999) Altitudinal distribution of leaf litter ants along a transect in primary forests on Mount Kinabalu, Sabah, Malaysia. Journal of Tropical Ecology 15(3): 265-2277.

COLLINGWOOD, C A (1970) Formicidae (Hymenoptera: Aculeata) from Nepal, Khumbu Himal 3(3): 371-2387.

DANIELS, R J R (1991) Ants as biological indicators of environmental changes. Blackbuck 7: 51-256.

DEL TORO, I; RIBBONS, R R; PELINI, S L (2012) The little things that run the world revisited: a review of ant-mediated ecosystem services and disservices (Hymenoptera: Formicidae). Myrmecological News 17:133-146.

ELMES, G W; RADCHENKO, A G (2009) Two new Himalayan ant species (Hymenoptera, Formicidae) related to Myrmica indica. Vestnik zoologii 43(2): 107-119.

FISHER, B L (2004) Diversity patterns of ants (Hymenoptera: Formicidae) along an elevational gradient on Monts Doudou in southwestern Gabon. Memoir 28: 269-2286.

FISHER, B L; ROBERTSON, H G (2002) Comparison and origin of forest and grassland Ant assemblages in the high plateau of Madagascar (Hymenoptera: Formicidae). Biotropica 34: 155-167.

FOLGARAIT, P J (1998) Ant biodiversity and its relationship to ecosystem functioning: a review. Biodiversity and Conservation 7: 1221-1244.

GADAGKAR, R; NAIR, P; CHANDRASHEKARA, K; BHAT, D M (1993) Ant species richness and diversity in some selected localities in western Ghats, India. Hexapoda 5(2): 79-294. 
GOTELLI, N J; ELLISON, A M; DUNN, R R; SANDERS, J N (2010) Forthcoming. Counting ants (Hymenoptera: Formicidae): biodiversity sampling and statistical analysis for myrmecologists. Myrmecological News 15:13-219.

GUENARD, B (2013) An overview of the species and ecological diversity of ants. Elsevier. Doi: 10.1002/9780470015902.a0023598.

KING; J R; PORTER, S D (2005) Evaluation of sampling methods and species richness estimators for ants in upland ecosystems in Florida. Environmental Entomology 34: 1566-21578.

LACH, L; TILLBERG, C V; SUAREZ, A V (2010) Contrasting effects of an invasive ant on a native and an invasive plant. Biological Invasions 12(9): 3123-3133.

LINDSEY, PA; SKINNER, J D (2001) Ant composition and activity patterns as determined by pitfall trapping and other methods in three habitats in the semi-arid Karoo. Journal of Arid Environments 48(4): 551-568.

LONGINO, J T; COLWELL, R K (1997) Biodiversity assessment using structured inventory: Capturing the ant fauna of a tropical rain forest. Ecological Applications 7: 1263-1277.

LOPES, C T; VASCONCELOS, H L (2008) Evaluation of three methods for sampling ground-dwelling ants in the Brazilian Cerrado. Neotropical Entomology 37: 399-405.

MAETO, K; SATO, S (2004) Impacts of forestry on ant species richness andcomposition in warmtemperate forests of Japan. Forest Ecology and Management 187(2-3): 213-223.

MAJER, J D (1997) The use of pitfall traps for sampling ants- a critique. Memoires of the Museum of Victoria 56(2): 323-329.

OLSON, D M (1991) A comparison of the efficacy of litter sifting and pitfall traps for sampling leaf litter ants (Hymenoptera, Formicidae) in a tropical wet forest, Costa Rica. Biotropica 23(2): 166-172.

READ, J L; ANDERSEN, A N (2000) The value of ants as early warning bioindicators: responses to pulsed cattle grazing at an Australian arid zonelocality. Journal of Arid Environments 45: 231-251.

ROMERO, H; JAFFE, K (1989) A comparison of methods for sampling ants (Hymenoptera, Formicidae) in Savannas. Biotropica 21(4): 348-352.

SABU, T K; VINEESH, P J; VINOD, K V (2008). Diversity of forest litter-inhabiting ants along elevations in the Wayanad region of the western ghats. Journal of Insect Science 8: 69.

SAMSON, D A; RICKART, EA; GONZALES, PC (2006) Ant diversity and abundance along an elevational gradient in the Philippines. Biotropica 29: 349-363.

SANDERS, N J (2002) Elevational gradients in ant species richness: area, geometry, and Rapoport's rule. Ecography 25: 25-32.

STORK, N E (1991) The composition of the arthropod fauna of Bornean lowland rain forest trees. Journal of Tropical Ecology 7: 161-180.

TURNER E C; FOSTER W A (2009) The impact of forest conversion to oil palm on arthropod abundance and biomass in Sabah, Malaysia. Journal of Tropical Ecology 25: 23-30.

WETTERER, J K (2017) Geographic distribution of the weaver ant (Oecophylla smaragdina). Asian Myrmecology 9: 1-12.

WILSON, E O (1975) Sociobiology: the new synthesis. Belknap Press of Harvard University Press, Cambridge, USA.

ZAR, J H (1999) Biostatistical analysis. New Jersey, USA (4th edition). 


\section{APPENDIX 1}

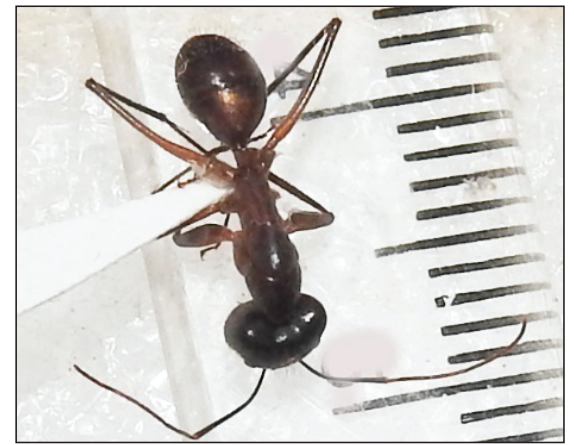

PLATE 1 Camponotus sp. (Formicinae)

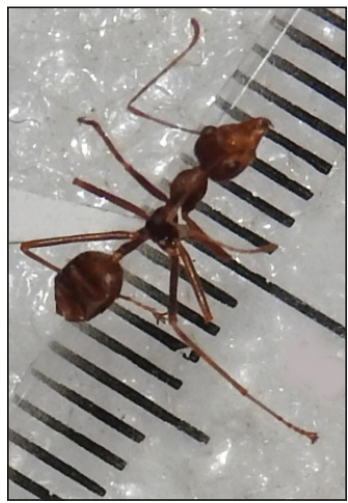

PLATE 3 Crematogaster sp. (Myrmicinae)

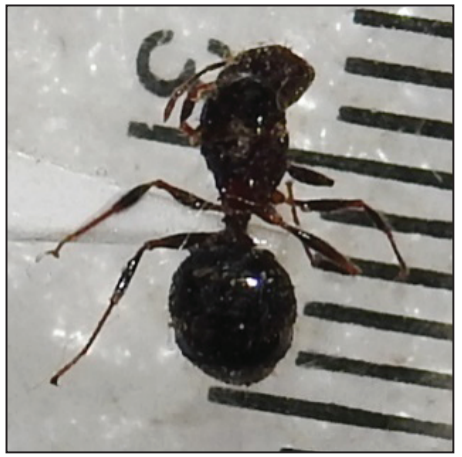

PLATE 2 Echinopla sp. (Formicinae)

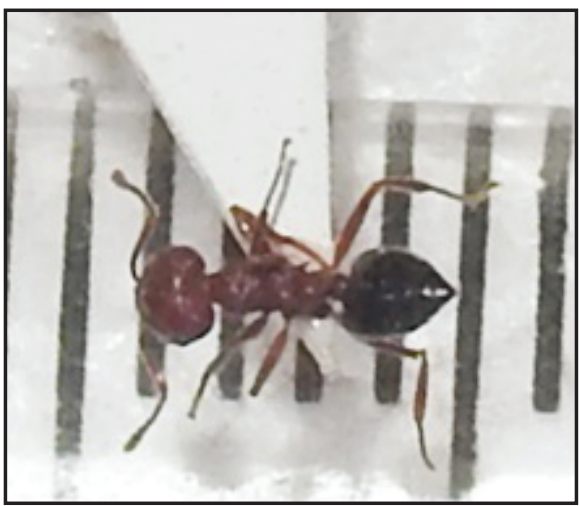

PLATE 4 Oecophylla sp. (Formicinae)

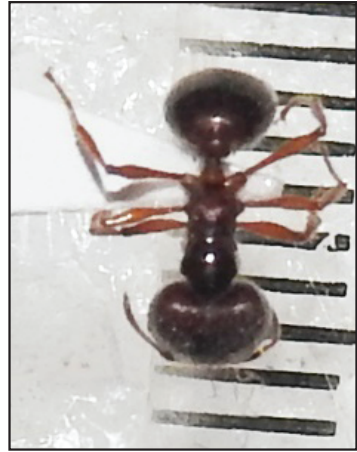

PLATE 5 Pheidole sp. (Myrmecinae) 